\title{
Removal of Various Contaminants by Highly Porous Activated Carbon Sorbent Derived from Agricultural Waste Produced in Malaysia - A Review
}

\author{
N.Z. Zabi, W.N. Wan Ibrahim $\dagger$, N.S. Mohammad Hanapi and N. Mat Hadzir \\ Faculty of Applied Sciences, Universiti Teknologi MARA, 40450 Shah Alam, Selangor, Malaysia \\ Corresponding author: W.N. Wan Ibrahim; wannazihah@uitm.edu.my
}

Nat. Env. \& Poll. Tech.

Website: www.neptjournal.com

Received: 28-05-2020

Revised: $29-07-2020$

Accepted: 16-09-2020

Key Words:

Activated carbon

Adsorption

Agricultural waste

Environmental pollutants

\begin{abstract}
This paper aims to review recent studies in preparing activated carbons from different types of agricultural wastes in Malaysia and how it can help Malaysia manage agricultural waste. It can be seen that most biomasses can be used as precursors to produce activated carbon for a wide range of pollutants and this adsorbent can be modified to optimally function depending on the types of pollutants. Under optimum dosages, modification through chemical activation using acidic, basic, or drying agents has significant effects on the selectivity of the analyte adsorption. The acidic activating agent causes the activated carbon to have negatively charged acid groups which enable it to adsorb cationic adsorbate while the basic activating agent causes the adsorbent to have a positive surface charge and enable it to adsorb anionic adsorbate.
\end{abstract}

\section{INTRODUCTION}

In Malaysia, the agricultural sector contributes $7.3 \%$ to the Gross Domestic Product (GDP). In 2018, oil palm (37.9\%) was the major contributor to the GDP of the agricultural sector followed by other agricultural products $(25.1 \%)$ such as paddy, cocoa beans, pepper, kenaf (dried stem), and rubber which contributed $2.8 \%$ per year (Department of Statistics Malaysia 2019). Since oil palm is the major contributor, $77 \%$ of total residues are from the oil palm industry, 9.1\% of rice residues, $8.2 \%$ of forestry residues and $5.7 \%$ of other residues like rubber, cocoa, and coconut (Griffin et al. 2014).

The waste management expenditure increased from RM 755.5 million to RM 789.0 million from the year 2015 to 2017 and constantly has become a challenge to manage the wastes (Department of Statistics Malaysia 2019). In the agricultural sector, the simplest way to dispose of the wastes is through burning but it causes serious air pollution (Teimouri et al. 2019). However, agricultural wastes are renewable sources that can be converted into energy, bio-based products, and value-added products (Marsin et al. 2018). Thus, there are many studies and reviews on how these biomasses can be useful resources instead of disposing them (Sulaiman et al. 2011, Saba et al. 2015, Aditiya et al. 2016). Some studies used agricultural wastes as potential biosorbent such as activated carbon (Teimouri et al. 2019).

Originally, coal was the best source of activated carbon but it is limited and non-renewable. Therefore, agricultural waste was used as an alternative source to produce activated carbon since it is renewable and low-cost (Danish \& Ahmad 2018). Activated carbons produced from biomasses are cheaper compared to commercialized activated carbon and can improve the economy by re-using these biomasses. Other than that, activated carbon obtained from biomasses may have a higher surface area compared to commercialized activated carbon. (Maneerung et al. 2016). Most agricultural wastes are lignocellulosic material and these types of materials are suitable to produce activated carbon (Nabais et al. 2013). Lignocellulosic material is a plant-based material, which is made of cellulose, hemicellulose, and lignin (Jiang et al. 2020). There are three major categories of this type of material which are wood-based like oak, energy crop like bamboo, and agricultural waste like palm and rubber trees (Ufodike et al. 2020). This paper reviews activated carbon produced from agricultural wastes that can be found in Malaysia and potentially act as an adsorbent to remove environmental pollutants from aqueous solutions.

\section{Activated Carbon from Agricultural Wastes}

Activated carbon can be produced through two types of activation process namely physical and chemical activation. The chemical properties (ash content and surface properties) and physical properties (surface area and pore size) depend on the types of the activation process. Chemical activation use dehydrating agents to impregnate the precursor material. The agent can either be acidic or basic depending on the analytes. 
Li et al. (2008) stated that physical activation involves two steps which are carbonization step $\left(400^{\circ} \mathrm{C}-850^{\circ} \mathrm{C}\right)$ and activation step $\left(600^{\circ} \mathrm{C}-900^{\circ} \mathrm{C}\right)$.

Cheah et al. (2013) stated that chemical activation has more advantages as it produces activated carbon with a higher BET surface area compared to physical activation. Comparison of two different studies that used the same precursor (oil palm shell), showed that activated carbon from physical activation obtained a lower BET surface area approximately 151 $\mathrm{m}^{2} \cdot \mathrm{g}^{-1}$ (Abioye \& Ani 2015) whereas a study that employed chemical activation obtained surface area of $1254 \mathrm{~m}^{2} \cdot \mathrm{g}^{-1}$ surface (Hoseinzadeh Hesas et al. 2013). Besides, chemical activation produces a higher yield of activated carbon, has less activation time, and provides suitable functional groups (Danish \& Ahmad 2018).

Chemical activating agents such as phosphoric acid and zinc chloride are always used to activate lignocellulosic material because these agents would immediately react with lignocellulose when mixed together (Yakout \& Sharaf ElDeen 2012). Zinc chloride can produce activated carbon in small and uniform-sized micropores (Hoseinzadeh Hesas et al. 2013) but phosphoric acid is more preferred because it produces both mesopores and micropores and safer compared to zinc chloride (Yacob et al. 2013). Gueye et al. (2014) reported that phosphoric acid depolymerized cellulose, hemicellulose, and lignin, which causes the formation of cross-linking through dehydration, cyclization, and condensation reaction. In addition, phosphoric acid also stimulates the formation of phosphate and polyphosphate bridges, which connects and cross-links the fragments obtained from macromolecules. Hui and Zaini (2015) stated that potassium hydroxide is also used to activate lignocellulosic material since it can produce well-developed pores and high specific surface areas. Unfortunately the activated carbon yield is frequently low. This is supported by the study of Foo and Hameed (2011) who managed to produce activated carbon with total surface area, total pore volume, and average pore size of $807.54 \mathrm{~m}^{2} \cdot \mathrm{g}^{-1}$, $0.45 \mathrm{~cm}^{3} \cdot \mathrm{g}^{-1}$, and $2.193 \mathrm{~nm}$ respectively.

Besides that, activated carbon can have different types of pores based on their pore sizes. Xue et al. (2019) stated that pore size can be characterized as ultramicropore $(<0.7$ $\mathrm{nm})$, supermicropore $(0.7 \mathrm{~nm}-2.0 \mathrm{~nm})$, small mesopore $(2.0$ $\mathrm{nm}-2.5 \mathrm{~nm})$ and large mesopore $(2.5 \mathrm{~nm}-50 \mathrm{~nm})$. The types of pores depend on activating agents used and also activation temperature. Heidari et al. (2014) showed that a high percentage of micropore can be obtained using potassium hydroxide and zinc chloride. For phosphoric acid, mesopores can be formed due to the presence of phosphate linkage that expands the biomass structure.

Chen et al. (2017) used phosphoric acid activation to produce activated carbon with high BET surface area and large pore volume. The hydrochar described here can be obtained from hydrothermal carbonization of corn cob residue (CCR). The porous structure of activated carbons was characterized by nitrogen adsorption and scanning electron microscopy (SEM). Results showed that the specific surface area and total pore volume of activated carbon were increased to $2192 \mathrm{~m}^{2} \cdot \mathrm{g}^{-1}$ and $1.269 \mathrm{~cm}^{3} \cdot \mathrm{g}^{-1}$, respectively, under conditions of $400^{\circ} \mathrm{C}, 1 \mathrm{~h}$, and an impregnation ratio of 3 , from $5.69 \mathrm{~m}^{2} \cdot \mathrm{g}^{-1}$ and 0.136 $\mathrm{cm}^{3} \cdot \mathrm{g}^{-1}$ of the starting material. The chemical properties of hydrochar and activated carbons were further characterized by Fourier transform infrared spectroscopy (FT-IR), which confirmed the chemical transformation. Furthermore, the localized graphitic nature of the porous carbon was shown by the X-ray diffraction pattern. Thus, the adsorption capacity was enhanced for activated carbon in comparison with commercial carbon. The process of activated carbon preparation provided a high value-added application of hydrochar.

In recent years, many researchers developed activated carbon from different types of biomass for various application such as adsorption (Kaveeshwar et al. 2018), catalyst supports (Mateo et al. 2020), medicine (Lakshmi et al. 2018), electrode materials (Tripathi et al. 2020), air filters (Gallego et al. 2013) and gas storage (Biloé et al. 2002). This is because activated carbon can be produced in large quantities (Mateo et al. 2020). Synthesis of activated carbon from biomass can reduce environmental pollution and the cost of disposal (Muniandy et al. 2014). Although activated carbons from biomasses are used in many industrial applications, the biggest challenge in producing activated carbon is the cost of production, uncertain methods, and also regeneration process (Danish \& Ahmad 2018). Table 1 and Table 2 shows properties of activated carbon from agricultural wastes produced through chemical activation and physical activation respectively.

\section{Activated Carbon as Adsorbent}

In the adsorption process, adsorbent primarily depends on the surface chemistry and pore structure of the material. Method of activation and nature of precursor tremendously affect the surface functional groups and pore structure. The surface functional groups provide vital information involving removal of cationic and anionic adsorbate (Marsin et al. 2018). For example, when activated carbon is treated with acid, the activated carbon will have negatively charged acid groups and able to adsorb cationic adsorbate and vice versa (Bhatnagar et al. 2013).

\section{Removal of Dyes using Activated Carbon}

Dye is a molecule that contains chromophore and auxochrome. The chromophore group causes the dye to have 
Table 1: Properties of activated carbons produced through chemical activation.

\begin{tabular}{|llll|}
\hline Material & Agent & $\mathrm{S}_{\mathrm{BET}}\left(\mathrm{m}^{2} \cdot \mathrm{g}^{-1}\right)$ & Reference \\
\hline Coconut spathe & $\mathrm{KOH}$ & 1705 & Prashanthakumar et al. (2018) \\
Rice husk & $\mathrm{NaOH}$ & 2786 & Zhang et al. (2020) \\
Coconut shell & $\mathrm{KOH}$ & 265 & Purnomo et al. (2018) \\
Oil palm kernel shell & $\mathrm{H}_{3} \mathrm{PO}_{4}$ & 630 & Yacob et al. (2013) \\
Cocoa shell & $\mathrm{H}_{3} \mathrm{PO}_{4}$ & 1077 & Pereira et al. (2014) \\
Oil palm empty fruit bunch & $\mathrm{KOH}$ & 807.54 & Foo and Hameed (2011) \\
Rubber seed shell & $\mathrm{KOH}^{\text {Oil palm shell }}$ & 620 & Pagketanang et al. (2015) \\
Kenaf stem & $\mathrm{ZnCl}_{2}$ & 1254 & Hoseinzadeh Hesas et al. (2013) \\
\hline
\end{tabular}

Table 2: Properties of activated carbons produced through physical activation.

\begin{tabular}{|llll|}
\hline Materials & Agent & $\mathrm{S}_{\mathrm{BET}}\left(\mathrm{m}^{2} \cdot \mathrm{g}^{-1}\right)$ & Reference \\
\hline Oil palm empty fruit bunch & Steam & 718 & Kadir et al. (2014) \\
Rice straw & $\mathrm{Steam}$ & 243 & Yang et al. (2020) \\
Cocoa shell & $\mathrm{CO}_{2}$ & 558.25 & Ahmad et al. (2013) \\
Oil palm shell & $\mathrm{CO}_{2}$ & 151 & Abioye and Ani. (2015) \\
Coconut shell & $\mathrm{CO}_{2} /$ Steam & 610 & Chandana et al. (2019) \\
Rubberwood sawdust & $\mathrm{CO}_{2}$ & 465 & Mazlan et al. (2016) \\
Coconut husk & $\mathrm{Steam}$ & 415.85 & Fu et al. (2020) \\
Oil palm shell & $\mathrm{CO}_{2}$ & 905 & Herawan et al. (2013) \\
Waste tea & $\mathrm{Steam}$ & 995 & Zhou et al. (2018) \\
\hline
\end{tabular}

its own color since it has a double bond that oscillates to adsorb light (Liang et al. 2014). Dyes are commonly used in foods, clothes, and also medicines which has increased the production rate of dyes. Many different types of dyes have been produced such as acidic, basic, disperse, azo, anthraquinone based and metal complex dyes (Ratna \& Padhi 2012).

Dyes can have health effects due to their toxicity and non-biodegradable characteristics (Kalkan et al. 2013). Examples of health problems are cancer, allergic respiratory problem, and skin and mucous membrane irritation (Kausar et al. 2018). Besides health effects, dyes also cause environmental pollution as it affects the symbiotic process in water as it prevents light penetration and causes the photosynthetic activity to decrease (Nidheesh et al. 2018).

It is difficult to remove dyes using ordinary water treatments due to its complex chemical structure and poor biodegradability (Khorasani \& Shojaosadati 2019). Therefore, a lot of studies have been conducted to find the best methods to remove dyes such as flocculation or coagulation (Sharma et al. 2011), electrochemical destruction (Narayana \& Kariyajjanavar 2019), ozonation (Sekar 2008), and ion exchange
(Yang et al. 2019). However, adsorption is preferable since it is more efficient and easier to conduct (Rai et al. 2015). There are various adsorbents that have been introduced such as disposable paper cups (Shukla et al. 2020), chitosan/polyamide nanofibers (Dotto et al. 2017), and amino grafted MCM-41 (Rizzi et al. 2019) but activated carbon is still the most used adsorbent because of its remarkable characteristics (Maneerung et al. 2016). Table 3 summarizes activated carbon from different agricultural wastes for the removal of dyes.

Macedo et al. (2006) prepared mesoporous activated carbon from coconut coir dust to remove methylene blue (cationic) and remazol yellow (anionic) dyes. Zinc chloride was used as an activating agent with a ratio of $3 \mathrm{ZnCl}_{2}: 1$ coir dust. This adsorbent contained both acidic and basic sites which enabled it to adsorb both basic and acidic dyes simultaneously. The study revealed that the interaction forces between the adsorbent and dyes are related to the $\mathrm{pH}$ solution which affects the charge distribution on the adsorbent surface. The optimum $\mathrm{pH}$ to adsorb methylene blue was $\mathrm{pH} 8$ while remazol yellow was $\mathrm{pH} 4$. In addition, the activated carbon had a short equilibrium time (approximately $120 \mathrm{~min}$ ) to adsorb both dyes. 
Sellaoui et al. (2017) used cocoa shells as a source of activated carbon to adsorb reactive violet 5 dye. The adsorption process is described as multilayer adsorption and it is thermally activated where the number of dye molecules per site increases when the temperature increases. From this study, the number of dye molecules per site on cocoa shell activated carbon is higher compared to commercialized activated carbon due to the interaction between functional groups in cocoa shell activated carbon and dye.

Guo et al. (2020) modified the activated carbon produced from peanut shell with $\mathrm{FeCl}_{3}$ and $\mathrm{MgCl}_{2}$ as a bimetallic activating agent to remove malachite green. Prepared adsorbent obtained a total surface area of $633.35 \mathrm{~m}^{2} . \mathrm{g}^{-1}$ with a high maximum adsorption capacity of $4031.96 \mathrm{mg}^{-\mathrm{g}^{-1}}$. The high adsorption rate is due to the increment of the area of the adsorbent rather than the change of contact areas between the adsorbent and the dye. The adsorption rate was narrowed to the intra-particle diffusion rate of dye molecules compared to the availability of active sites. Interactions between MG dye and Fe-Mg15 including the H-bonding, $\pi$ - $\pi$ stacking, and the electrostatic attraction triggered considerable adsorption performance. The dominant interaction was the H-bonding between $\mathrm{Mg}-\mathrm{OH}$ and $\mathrm{N}$-containing groups in $\mathrm{MG}$. The chemical regeneration method could not have achieved an effective removal of adsorbed malachite green, whereas the adsorptive properties of $\mathrm{Fe}-\mathrm{Mg}$ BACs could be well regenerated via the thermal regeneration method. The adsorption for this study fits the Freundlich isotherm model.

Mahamad et al. (2015) used activated carbon produced from pineapple biomass to remove methylene blue from an aqueous solution. The total surface area of the adsorbent was $914.67 \mathrm{~m}^{2} \cdot \mathrm{g}^{-1}$ with a maximum adsorption capacity of $288.34 \mathrm{mg} . \mathrm{g}^{-1}$. In this study, the mechanism involved in the removal of the dye was the migration of dye from the bulk of solution and diffusion of the dye through boundary layer to surface of the adsorbent and intra-particle diffusion of dye into interior pores of adsorbent. The boundary layer resistance was affected by the rate of adsorption.

Islam et al. (2017) produced mesoporous activated carbon using hydrochar prepared from coconut shell. The maximum adsorption capacity was $200.01 \mathrm{mg} \cdot \mathrm{g}^{-1}$ and the total surface area of the adsorbent was $876.14 \mathrm{~m}^{2} \cdot \mathrm{g}^{-1}$. The adsorption in this study fitted the Langmuir isotherm and pseudo-second-order model. Results showed higher adsorption of dye when $\mathrm{pH}$ increased from 7 to 9 , due to the high number of -OH groups which contributed a slightly negative charge on the surface and enhanced the adsorption of the dye.

\section{Removal of Pesticides Using Activated Carbon}

Pesticides are chemically prepared from different types of substances such as such as fungicides, rodenticides, weed killers, insecticides, and antimicrobials (Elhag et al. 2017). This organic material is used to kill targeted pests (Chawla et al. 2018). Pesticides can be divided into classes which are organophosphates, organochlorine, carbamates, chlorophenol, and synthetic pyrethroids pesticides (Hamza et al. 2016). Organophosphorus pesticides (OPs) are the most used pesticides in agriculture because it is more biodegradable and has shorter persistence compared to organochlorine pesticides (Chen et al. 2010). It protects the crops by inhibiting acetylcholinesterase enzyme activity in insects (Sapahin et al. 2014).

Nonetheless, continuous and excessive usage of pesticides inadequately can lead to many environmental and health problems (Blankson et al. 2016). As a matter of fact, improper use of any kind of pesticides can cause agricultural products to have residues of it (Chen et al. 2010). There are few major groups of pesticides that are carcinogenic to living organisms which are organophosphates, organochlorines, carbamates, and pyrethroids (George \& Shukla 2011).

Table 3: Literature studies on different agricultural wastes for removal of dyes.

\begin{tabular}{|llllll|}
\hline Materials & Activation method & Activation agent & Dyes & Removal uptake (mg.g ${ }^{-1}$ ) & Reference \\
\hline $\begin{array}{l}\text { Oil palm empty } \\
\text { fruit bunch }\end{array}$ & Chemical & $\mathrm{KOH}$ & Methylene blue (Cationic) & 344.83 & Foo and Hameed (2011) \\
$\begin{array}{l}\text { Coconut coir } \\
\text { dust }\end{array}$ & Chemical & $\mathrm{ZnCl}_{2}$ & Methylene blue & 14.36 & Macedo et al. (2006) \\
Cocoa shell & Chemical & $\mathrm{ZnCl}_{2} / \mathrm{FeCl}_{3}$ & Reactive violet 5 & n.a. & Sellaoui et al. (2017) \\
$\begin{array}{l}\text { Peanut shell } \\
\text { Pineapple waste }\end{array}$ & Chemical & $\mathrm{FeCl}_{3} / \mathrm{MgCl}_{2}$ & Malachite green (Cationic) & 4031.96 & Guo et al. (2020) \\
Oil palm shell & Chemical & $\mathrm{ZnCl}_{2}$ & Methylene blue & 288.34 & Mahamad et al. (2015) \\
Coconut shell & Chemical & $\mathrm{KOH}$ & Methylene blue & 243.90 & Tan et al. (2008) \\
\hline
\end{tabular}

*n.a. - not available 
Besides health problems, pesticides affect the ecosystems as well due to their persistent nature. (Marican \& Durán-Lara 2017). Thus, monitoring residues of pesticides in soil, water, plants, and food is important.

There are three types of methods to remove pesticides which are biological, chemical, and physical processes (Mojiri et al. 2020) For biological processes, Nie et al. (2020) used microalgae to bioremediate water containing pesticides. Fiorenza et al. (2020) used a chemical process to remove pesticides from water by molecular imprinting on titanium dioxide photocatalyst. For physical processes, the most common technique is adsorption. Table 4 summarizes activated carbon from different agricultural wastes for the removal of pesticides.

Chang et al. (2014) used rice straw as a precursor to remove carbofuran from an aqueous solution. Based on this study, the adsorption of the pesticides was optimum at a lower $\mathrm{pH}$ and temperature. At a high temperature, the target molecules eluded from solid phase to bulk phase due to an increase in energy while at high $\mathrm{pH}$ value. Carbofuran tends to deprotonate due to the presence of $\mathrm{OH}^{-}$ions and this causes weaker interaction between the neutral molecular form of carbofuran with the adsorbent. The adsorption process best fits the Langmuir model. The maximum carbofuran adsorption capacity was $296.52 \mathrm{mg} . \mathrm{g}^{-1}$.

Salman et al. (2011) removed 2,4-dichlorophenoxyacetic acid from an aqueous solution. The activated carbon was produced from the oil palm frond. Based on the result, the adsorption of the pesticides depended on the availability of sites on the adsorbent compared to the concentration of the pesticides. The adsorption process best fits the Langmuir model. Ioannidou et al. (2010) used four agricultural residues as sources of activated carbon (olive kernel, corn cob, rapeseed stalks. and soya stalks). However, corn cob activated carbon had the highest adsorption capacity which is $18.9 \times 10^{-2} \mathrm{mg} \cdot \mathrm{g}^{-1}$ since it contains more micropores and also spongy like cross-interconnected pores.

Abdelhameed et al. (2020) used orange peel and apricot kernel to produce activated carbon for the removal of prothiofos and its degradation compounds from an aqueous solution. Based on the result, the maximum adsorption capacities of the pesticide were $185.9 \pm 1.8 \mathrm{mg}^{-1} \mathrm{~g}^{-1}$ and 145.8 $\pm 2.4 \mathrm{mg} \cdot \mathrm{g}^{-1}$ for orange peel and apricot kernel, respectively. The adsorption process best fits the Langmuir model. The adsorption of the pesticides occurs when prothiofos that contain $\mathrm{P}-\mathrm{O}$ functional groups bind with free hydroxyl and carboxyl groups of the adsorbent through hydrogen bonds.

\section{Removal of Polycyclic Aromatic Hydrocarbon using Activated Carbon}

Polycyclic aromatic hydrocarbons (PAHs) are a group of compounds, which are composed of two or more fused aromatic rings (Cao et al. 2017). PAHs have different functional groups in the benzene rings or lateral chains which causes it to have different chemical properties (Tsibart \& Gennadiev 2013). PAHs are usually emitted as a mixture and the relative molecular concentration ratios are usually treated as the characteristics of the emission source (Tobiszewski \& Namieśnik 2012).

Every year, there are production and processing of plasticizers, dyes, and pigments that cause the release of PAHs. Besides that, PAHs can also enter the environment through incomplete combustion processes such as the processing of coal and crude oil during refining, coal gasification, and coking (Pérez-Gregorio et al. 2010). The prevalence of this compound is released into various water bodies which will cause serious health and environmental problems (Mojiri et al. 2019). PAHs are known for their genotoxic, mutagenic, and carcinogenic effects on humans (Idowu et al. 2019). Other than that, due to its persistent nature, toxicity and bioaccumulation this compound also affects the environment especially soil.

Thus, it is necessary to remove this compound from the environment. Chemical such as chemical precipitation and solvent liquid-liquid extraction (Ates \& Argun 2018, Naik et al. 2017) and biological methods such as phytoremediation technology (Włóka et al. 2019) are used to remove PAHs,

Table 4: Literature studies on different agricultural wastes for removal of pesticides.

\begin{tabular}{|c|c|c|c|c|c|}
\hline Materials & Activation method & Activation agent & Pesticides & $\begin{array}{l}\text { Removal uptake/ } \\
\text { percentage }\end{array}$ & Reference \\
\hline Rice straw & Chemical & $\mathrm{KOH}$ & Carbofuran & $296.52 \mathrm{mg} \cdot \mathrm{g}^{-1}$ & Chang et al. (2014) \\
\hline Oil palm frond & Chemical & $\mathrm{KOH}$ & 2,4-dichlorophenoxyacetic acid & $352.89 \mathrm{mg} \mathrm{g}^{-1}$ & Salman et al. (2011) \\
\hline Corn cobs & Physical & Steam & Bromopropylate & $18.9 \times 10^{-2} \mathrm{mg} \cdot \mathrm{g}^{-1}$ & Ioannidou et al. (2010) \\
\hline Orange peel & Physical & Hot air & Prothiofos & $185.9 \pm 1.8 \mathrm{mg} \cdot \mathrm{g}^{-1}$ & Abdelhameed et al. (2020) \\
\hline Coconut frond & Chemical & $\mathrm{H}_{3} \mathrm{PO}_{4}$ & Carbofuran & $80 \%$ & Njoku et al. (2014) \\
\hline Oil palm shell & Chemical & $\mathrm{NaOH}$ & 4-chloroguaiacol & $454.45 \mathrm{mg} \cdot \mathrm{g}^{-1}$ & Hamad et al. (2010) \\
\hline
\end{tabular}


however some of the techniques produce toxic by-products. Due to this occurrence, physical methods such as filtration (Ndiaye et al. 2005) and adsorption (Kumar et al. 2019) are commonly used. Compared to other physical methods, adsorption is the best method because of its safety, affordability, universal nature, and simple operation process (Akinpelu et al. 2019). Table 5 summarize activated carbon from agricultural waste for the removal of PAHs compounds.

Kumar et al. (2019) used palm shells as a source of activated carbon. The activated carbon was modified through pyrolysis to increase the adsorption of PAH compounds. The activated carbons have been induced with potassium hydroxide. Based on the result, the maximum adsorption capacity of acenaphthalene for pyrolysis-assisted activated carbon (131.7 mg. $\mathrm{g}^{-1}$ ) was higher than normal activated carbon (96.54 mg. $\left.\mathrm{g}^{-1}\right)$ because it had a higher surface area (430 $\left.\mathrm{m}^{2} \cdot \mathrm{g}^{-1}\right)$ compared to normal activated carbon $\left(286 \mathrm{~m}^{2} \cdot \mathrm{g}^{-1}\right)$. Both adsorption process fits the Freundlich model which shows heterogeneous adsorption.

Gupta and Gupta (2015) produced activated carbon from banana peel to remove naphthalene, fluorene, and phenanthrene from aqueous system. The adsorbent had good adsorption capacity and a large BET surface area $\left(>900 \mathrm{~m}^{2} \cdot \mathrm{g}^{-1}\right)$. Since the adsorption process was endothermic (positive enthalpy change, $\Delta \mathrm{H}^{\circ}$ ), the adsorption of PAH compounds was better at a higher temperature. Besides that, a positive value of entropy change, $\Delta S^{\circ}$ showed that the adsorption process was spontaneous and good affinity between PAHs and adsorbent because there was an increase in randomness at the interface (solid/liquid). Gupta (2015) used orange rind as a source of activated carbon. In this study, the adsorption of PAH compounds was preferable at lower $\mathrm{pH}$ because the adsorbent surface had a more positive charge due to the presence of $\mathrm{H}^{+}$ions and which has led to high interaction between the adsorbent surface and $\pi$-electron cloud of phenanthrene molecules.
Yakout et al. (2013) used rice husk to produce activated carbon. The activated carbon was used to adsorb naphthalene, phenanthrene, and pyrene. Based on the result, the adsorption of PAH compounds onto the adsorbent depended on the weight and solubility of the adsorbate. There was a higher removal rate of pyrene followed by phenanthrene and naphthalene.

\section{Removal of Heavy Metal using Activated Carbon}

Heavy metals are metals that have densities greater than 5 g. $\mathrm{cm}^{-3}$ such as arsenic, cadmium, chromium, mercury, lead, copper, zinc, and nickel (Chen et al. 2015). Heavy metal pollution is one of the most serious environmental problems. Industries such as metal plating, mining operations, surface finishing industry, radiator manufacturing, alloy, and batteries industries usually release heavy metals in wastewater (Tounsadi et al. 2016). Other than that, nickel and zinc are persistent in nature and tend to accumulate in soils and plants which can be transferred to living organisms through the food chain (Alam et al. 2020). When humans or animals consume any of these heavy metals it can cause negative health effects like cancer, nausea, vomiting, mental retardation, liver, and kidney failure (Masjedi et al. 2020).

Therefore, the removal of heavy metals from the environment is important. There are three types of methods to remove heavy metal ions which are biological methods such as synergistic actions of microorganisms and waste molasses (Sun et al. 2020), a chemical method such as joint EDTA-acid treatment (Kou et al. 2020), and physical method such as adsorption using nanoparticles (Das \& Rebecca 2018). Although nowadays, the removal of pollutants using activated carbon is considered an effective purification process since it can reduce trace amounts of heavy metal to reach environmental standards and regulations (Treviño-Cordero et al. 2013). Table 6 summarizes activated carbon from agricultural waste for the removal of heavy metals.

Table 5: Literature studies on different agricultural wastes for removal of PAHs compounds.

\begin{tabular}{|c|c|c|c|c|c|}
\hline Materials & Activation method & Activation agent & PAHs & $\begin{array}{l}\text { Removal uptake } \\
(\mathrm{mg} \cdot \mathrm{g}-1)\end{array}$ & Reference \\
\hline Palm shell & Chemical & $\mathrm{KOH}$ & Acenaphthalene & 131.7 & Kumar et al. (2019) \\
\hline \multirow[t]{3}{*}{ Banana peel } & Physical & n.a. & Naphthalene & 333.33 & Gupta and Gupta. (2015) \\
\hline & & & Fluorene & 285.71 & \\
\hline & & & Phenanthrene & 217.39 & \\
\hline Orange rind & Chemical & $\mathrm{H}_{3} \mathrm{PO}_{4}$ & Phenanthrene & 70.92 & Gupta (2015) \\
\hline \multirow[t]{3}{*}{ Rice husk } & Chemical & $\mathrm{H}_{3} \mathrm{PO}_{4}$ & Naphthalene & n.a. & Yakout et al. (2013) \\
\hline & & & Phenanthrene & n.a. & \\
\hline & & & Pyrene & n.a. & \\
\hline
\end{tabular}

*n.a. - not available 
Chandana et al. (2019) produced activated carbon using coconut shells to remove $\mathrm{Cr}(\mathrm{VI})$ from industrial overflows. The activated carbon was produced through physical activation with three different types of activating agents. From the study, the best activating agent was a mixture of carbon dioxide and steam with a surface area of $610 \mathrm{~m}^{2} \cdot \mathrm{g}^{-1}$. The adsorption of $\mathrm{Cr}(\mathrm{VI})$ depended on the $\mathrm{pH}$ of the solution and showed maximum adsorption capacity $\left(\sim 26 \mathrm{mg} \cdot \mathrm{g}^{-1}\right)$ at $\mathrm{pH} 2$.

Borhan et al. (2016) prepared activated carbon from rubber seed shells to remove copper (II) and zinc ions from an aqueous solution. Based on the result, the highest percentage removal of copper (II) ions and zinc ions were $99.6 \%$ and $94 \%$, respectively at the optimum condition of $200 \mathrm{ppm}$ of initial concentration, $400 \mathrm{rpm}$ stirring rate, and 45 minutes of contact time. This study stated that increasing the stirring rate causes a higher rate of diffusion of metal ions. This is because there was an enhancement of turbulence and reduction in thickness of the liquid boundary layer.

Rahman et al.(2014) produced activated carbon from oil palm shells and coconut shells to remove nickel (II), lead (II), and chromium (IV) ions from aqueous solution. The activated carbon from the oil palm shells was activated in two different impregnation conditions where the oil palm shell powder was either wet or semi-dried with phosphoric acid before placing it in the furnace. A comparison between prepared and commercial activated carbon was also made in this study. Based on the result, prepared activated carbons had higher adsorption capacity for $\mathrm{Ni}$ (II) and $\mathrm{Pb}$ (II) ions while commercial activated carbon was able to adsorb more $\mathrm{Cr}$ (IV) ions although it had lower adsorption capacity in a low concentration range. The adsorption process for $\mathrm{Ni}$ (II) and $\mathrm{Pb}$ (II) ions best fits the Langmuir model. For the adsorption process of $\mathrm{Cr}$ (IV) ions, only two adsorbents were used which are activated carbon from oil palm shells (semi-dried) and commercial activated carbon and the process best fits both Langmuir and Freundlich model. This study stated that the prepared activated carbon is more suitable to be used in drinking water purification compared to commercial activated carbon since it has a stronger affinity towards all heavy metals even at low concentrations. The removal uptake of heavy metal ions for every adsorbent is shown in Table 6 .

Chowdhury et al. (2012) used kenaf fiber as a starting material to produce activated carbon for the removal of copper (II) ions from wastewater. Based on the data, the adsorption process best fits the Langmuir model compared to Freundlich and this shows that it is a monolayer adsorption process. In addition, for kinetic study, the adsorption fits pseudo-second-order model where the rate-limiting step

Table 6: Literature studies on different agricultural wastes for removal of heavy metals.

\begin{tabular}{|c|c|c|c|c|c|}
\hline Materials & Activating method & Activating agent & Heavy metals & Removal uptake/percentage & Reference \\
\hline \multirow[t]{3}{*}{ Coconut shell } & \multirow[t]{3}{*}{ Physical } & $\mathrm{CO}_{2} /$ steam & $\mathrm{Cr}^{6+}$ & $\sim 26 \mathrm{mg} \cdot \mathrm{g}^{-1}$ & \multirow[t]{3}{*}{ Chandana et al. (2019) } \\
\hline & & $\mathrm{CO}_{2}$ & & n.a. & \\
\hline & & $\mathrm{O}_{3}$ & & n.a. & \\
\hline \multirow[t]{2}{*}{ Rubber seed shell } & \multirow[t]{2}{*}{ Chemical } & \multirow[t]{2}{*}{$\mathrm{KOH}$} & $\mathrm{Zn}^{2+}$ & $99.6 \%$ & \multirow[t]{2}{*}{ Borhan et al. (2016) } \\
\hline & & & $\mathrm{Cu}^{2+}$ & $94 \%$ & \\
\hline Kenaf fibre & Chemical & $\mathrm{KOH}$ & $\mathrm{Cu}^{2+}$ & n.a. & Chowdhury et al. (2012) \\
\hline \multirow[t]{3}{*}{ Oil palm shell (wet) } & \multirow[t]{3}{*}{ Chemical } & \multirow[t]{3}{*}{$\mathrm{H}_{3} \mathrm{PO}_{4}$} & $\mathrm{Ni}^{2+}$ & 10.83 & \multirow[t]{3}{*}{ Rahman et al. (2014) } \\
\hline & & & $\mathrm{Pb}^{2+}$ & 74.63 & \\
\hline & & & $\mathrm{Cr}^{4+}$ & n.a. & \\
\hline \multirow{3}{*}{$\begin{array}{l}\text { Oil palm shell } \\
\text { (semi-dried) }\end{array}$} & \multirow{3}{*}{ Chemical } & \multirow[t]{3}{*}{$\mathrm{H}_{3} \mathrm{PO}_{4}$} & $\mathrm{Ni}^{2+}$ & 19.61 & \multirow[t]{3}{*}{ Rahman et al. (2014) } \\
\hline & & & $\mathrm{Pb}^{2+}$ & 63.69 & \\
\hline & & & $\mathrm{Cr}^{4+}$ & 46.30 & \\
\hline \multirow[t]{3}{*}{ Coconut shell } & \multirow[t]{3}{*}{ Chemical } & \multirow[t]{3}{*}{$\mathrm{H}_{3} \mathrm{PO}_{4}$} & $\mathrm{Ni}^{2+}$ & 12.18 & \multirow[t]{3}{*}{ Rahman et al. (2014) } \\
\hline & & & $\mathrm{Pb}^{2+}$ & 73.53 & \\
\hline & & & $\mathrm{Cr}^{4+}$ & n.a. & \\
\hline \multirow{3}{*}{$\begin{array}{l}\text { Oil palm empty } \\
\text { fruit bunch }\end{array}$} & \multirow[t]{3}{*}{ Chemical } & \multirow[t]{3}{*}{$\mathrm{NaOH}$} & $\mathrm{Pb}^{2+}$ & $100 \%$ & \multirow[t]{3}{*}{ Wahi et al. (2009) } \\
\hline & & & $\mathrm{Hg}^{2+}$ & $100 \%$ & \\
\hline & & & $\mathrm{Cu}^{2+}$ & $25 \%$ & \\
\hline
\end{tabular}

$*$ n.a. - not available 
may be chemisorption which involves valency forces through sharing and exchange of electrons.

Wahi et al. (2009) prepared activated carbon from oil palm empty fruit bunch for removal of mercury, lead, and copper from aqueous solution. The EFB activated carbon showed excellent efficiency in removing $\mathrm{Pb}$ (II) and $\mathrm{Hg}$ (II) with a percentage of removal up to $100 \%$ even at low adsorbent dosage. In contrast, only $25 \%$ removal of $\mathrm{Cu}$ (II) by the EFB activated carbon was observed. The study also showed that the adsorption of $\mathrm{Hg}$ (II), $\mathrm{Pb}$ (II), and $\mathrm{Cu}$ (II) by EFB activated carbon is dependent on the dosage of adsorbent and initial metals concentration. The use of EFB as activated carbon is not only effective for $\mathrm{Hg}$ (II) and $\mathrm{Pb}(\mathrm{II})$ removal from wastewater but also helps in solving the problem of the over-abundance of EFB as an agricultural waste product. Based on the result, the adsorption of lead (II) and mercury (II) ions best fits the Freundlich model while the adsorption of copper (II) best fits the Langmuir model.

\section{Future Prospect of Activated Carbon from Agricultural Waste}

For the past years, most of the activated carbon produced from agricultural wastes is in powdered form. Recently, many studies have shifted their focus in producing activated carbon in fiber form and it is known as activated carbon fiber (ACF). This material is a combination of activated carbon and carbon fiber. Based on a review done by Hassan et al. (2020), there was an increasing number of publications ( $>300)$ about ACF from the year 2017 to 2019. The advantages of this material are higher adsorption rates, high accessible porosity, high surface area, improved contact efficiencies, adequate design flexibility, and easy regeneration. The four major precursors for the production of this material are polyacrylonitrile, phenolic resins, pitch resins, and bio-based materials mainly lignocellulosic. Therefore, for future studies, agricultural waste can be used as precursors to determine the best method to produce $\mathrm{ACF}$ as a highly potential adsorbent.

\section{CONCLUSION}

It is proven that agricultural biomasses can be used to produce activated carbon for the removal of different types of pollutants. This adsorbent is cheaper and sometimes even better than commercial activated carbon. By utilizing these wastes, it can reduce the expenditure for waste management and also improve the economy of this country. The biomass-based activated carbon can be a better adsorbent once surface modification through physiochemical methods is done. Different types of biomass require different activation treatments for optimum removal of targeted pollutants. For removal of dyes, chemical activation is preferable and adsorption efficiency can be increased by controlling the $\mathrm{pH}$ of the solution. For the removal of pesticides, the removal uptake using chemical activation is higher than physical activation since there are more pores formed and the presence of suitable active sites to adsorb the pesticides. For removal of PAHs compound, chemical activation using acid is preferable since the adsorption of PAHs is based on positive charge surface area and $\pi$-electron cloud. For the removal of heavy metals, using phosphoric acid as an activating agent has a high removal uptake of certain heavy metals. Besides that, choosing the right precursor is also important for the adsorption process because the precursor materials control the carbon pore structure.

\section{ACKNOWLEDGEMENTS}

The authors gratefully acknowledge Universiti Teknologi MARA for the facilitation and Ministry of Education Malaysia for their financial supports through vote number 600 IRMI/FRGS 5/3 (416/2019).

\section{REFERENCES}

Abdelhameed, R.M., Abdel-Gawad, H. and Hegazi, B. 2020. Effective adsorption of prothiofos (O-2,4-dichlorophenyl O-ethyl S-propyl phosphorodithioate) from water using activated agricultural waste microstructure. J. Environ. Chem. Eng., 8(3): 103768.

Abioye, A.M. and Ani, F.N. 2015. The characteristics of oil palm shell biochar and activated carbon produced via microwave heating. Retrieved April 13, 2020, from Applied Mechanics and Materials, website: http://www.scientific.net/AMM.695.12

Aditiya, H.B., Chong, W.T., Mahlia, T.M.I., Sebayang, A.H., Berawi, M.A. and Nur, H. 2016. Second-generation bioethanol potential from selected Malaysia's biodiversity biomasses: A review. Waste Manag., 47: 46-61.

Ahmad, F., Daud, W.M.A.W., Ahmad, M.A., Radzi, R. and Azmi, A.A. 2013. The effects of CO2 activation, on porosity and surface functional groups of cocoa (Theobroma cacao)-Shell-based activated carbon. J. Environ. Chem. Eng., 1(3): 378-388.

Akinpelu, A.A., Ali, M.E., Johan, M.R., Saidur, R., Qurban, M.A. and Saleh, T.A. 2019. Polycyclic aromatic hydrocarbons extraction and removal from wastewater by carbon nanotubes: A review of the current technologies, challenges, and prospects. Process Saf. Environ. Prot., 122: 68-82.

Alam, M., Hussain, Z., Khan, A., Khan, M. A., Rab, A., Asif, M., Shah, M. A. and Muhammad, A. 2020. The effects of organic amendments on heavy metals bioavailability in mine impacted soil and associated human health risk. Sci. Hort., 262: 109067.

Ates, H. and Argun, M.E. 2018. Removal of PAHs from leachate using a combination of chemical precipitation and Fenton and ozone oxidation. Water Sci. Technol., 78(5): 1064-1070.

Bhatnagar, A., Hogland, W., Marques, M. and Sillanpää, M. 2013. An overview of the modification methods of activated carbon for its water treatment applications. Chem. Eng. J., 219: 499-511.

Biloé, S., Goetz, V. and Guillot, A. 2002. Optimal design of activated carbon for an adsorbed natural gas storage system. Carbon, 40(8): 1295-1308.

Blankson, G.K., Osei-Fosu, P., Adeendze, E.A. and Ashie, D. 2016. Contamination levels of organophosphorus and synthetic pyrethroid 
pesticides in vegetables marketed in Accra, Ghana. Food Cont., 68: 174-180.

Borhan, A., Abdullah, N.A., Rashidi, N.A. and Taha, M.F. 2016. Removal of $\mathrm{Cu} 2+$ and $\mathrm{Zn} 2+$ from single metal aqueous solution using rubber-seed shell-based activated carbon. Procedi. Engi., 148: 694-701.

Cao, H., Chao, S., Qiao, L., Jiang, Y., Zeng, X. and Fan, X. 2017. Urbanization-related changes in soil PAHs and potential health risks of emission sources in a township in Southern Jiangsu, China. Science of The Total Environment., 575: 692-700.

Chandana, L., Krushnamurty, K., Suryakala, D. and Subrahmanyam, C. 2019. Low-cost adsorbent derived from the coconut shell for the removal of hexavalent chromium from an aqueous medium. Mater. Today: Proceed., 26: 1-8

Chang, K.L., Chen, C.C., Lin, J.H., Hsien, J.F., Wang, Y., Zhao, F., Shih, Y.H., Xing, Z.J. and Chen, S.T. 2014. Rice straw-derived activated carbons for the removal of carbofuran from an aqueous solution. New Carb. Mater., 29(1): 47-54.

Chawla, P., Kaushik, R., Shiva Swaraj, V.J. and Kumar, N. 2018. Organophosphorus pesticides residues in food and their colorimetric detection. Environ. Nanotechnol. Monit. Manag., 10: 292-307.

Cheah, W.K., Othman, R. and Yeoh, F.Y. 2013. Organic and inorganic acid activation of activated carbon fiber from palm oil empty fruit bunch. Adv. Mater. Res., 858: 122-130.

Chen, J., Duan, C. and Guan, Y. 2010. Sorptive extraction techniques in sample preparation for organophosphorus pesticides in complex matrices. J. Chrom. B., 878(17-18): 1216-1225.

Chen, H., Teng, Y., Lu, S., Wang, Y. and Wang, J. 2015. Contamination features and health risk of soil heavy metals in China. Sci. Tot. Environ., 512-513: 143-153.

Chen, J., Zhang, L., Yang, G., Wang, Q., Li, R. and Lucia, L. A. 2017. Preparation and characterization of activated carbon from hydrochar by phosphoric acid activation and its adsorption performance in prehydrolysis liquor. Bioresour., 12(3).

Chowdhury, Z.Z., Zain, S.M., Khan, R.A. and Islam, M.S. 2012. Preparation and characterizations of activated carbon from kenaf fiber for equilibrium adsorption studies of copper from wastewater. Kor. J. Chem. Eng., 29(9): 1187-1195.

Danish, M. and Ahmad, T. 2018. A review on the utilization of wood biomass as a sustainable precursor for activated carbon production and application. Renew. Sustain. Energy Rev., 87: 1-21.

Das, M.P. and Rebecca, L.J. 2018. Removal of lead (II) by phyto-inspired iron oxide nanoparticles. Nat. Environ. Pollut. Technol., 17(2): 569-574.

Department of Statistics Malaysia. 2019, May 31. Review of Survey of Environmental Protection Expenditure 2018. Retrieved May 11, 2020, from Department of Statistics Malaysia, Official Portal website: https://www. dosm.gov.my/v1/index.php?r=column/cthemeByCat\&cat=154\&bul_ id=L1BTVXhaaEFPeERDc2Y1K3JLWVdMQT09\&menu_id=NWVEZGhEVINMeitaMHNzK2htRU05dz09

Department of Statistics Malaysia. 2019, November 29. Review of Selected Agricultural Indicators, Malaysia, 2019. Retrieved May 11, 2020, from Department of Statistics Malaysia, Official Portal website: https://www. dosm.gov.my/v1/index.php?r=column/cthemeByCat\&cat=72\&bul_ id=SEUxMEE3VFdBcDJhdUhPZVUxa2pKdz09\&menu_id=Z0VTZGU1UHBUT1VJMFlpaXRRR0xpdz09

Dotto, G.L., Santos, J.M.N., Tanabe, E.H., Bertuol, D.A., Foletto, E.L., Lima, E.C. and Pavan, F.A. 2017. Chitosan/polyamide nanofibers prepared by force spinning technology: A new adsorbent to remove anionic dyes from aqueous solutions. J. Cleaner Prod., 144: 120-129.

Elhag, D.E., Abdalla, B.S., Suliman, S.A. and Ali, I. 2017. Multi-residue analysis of organophosphorus pesticides in vegetables using GC-MS. J. Agric. Chem. Environ., 6(4): 232-241.

Fiorenza, R., Di Mauro, A., Cantarella, M., Iaria, C., Scalisi, E.M., Brundo, M.V., Gulino, A., Spitaleri, L., Nicotra, G., Dattilo, S., Carroccio, S.C., Privitera, V. and Impellizzeri, G. 2020. Preferential removal of pesticides from water by molecular imprinting on $\mathrm{TiO} 2$ photocatalysts. Chem. Eng. J., 379: 122309.

Foo, K.Y. and Hameed, B.H. 2011. Preparation of oil palm (Elaeis) empty fruit bunch activated carbon by microwave-assisted $\mathrm{KOH}$ activation for the adsorption of methylene blue. Desalination, 275(1-3): 302-305.

Fu, J., Zhang, J., Jin, C., Wang, Z., Wang, T., Cheng, X. and Ma, C. 2020. Effects of temperature, oxygen, and steam on pore structure characteristics of coconut husk activated carbon powders prepared by the one-step rapid pyrolysis activation process. Bioresour. Technol., 310: 123413.

Gallego, E., Roca, F.J., Perales, J.F. and Guardino, X. 2013. Experimental evaluation of VOC removal efficiency of a coconut shell activated carbon filter for indoor air quality enhancement. Build. Environ., 67: 14-25.

George, J. and Shukla, Y. 2011. Pesticides and cancer: Insights into toxicoproteomic-based findings. J. Proteomics., 74(12): 2713-2722.

Griffin, W., Michalek, J., Matthews, H. and Hassan, M. 2014. Availability of biomass residues for co-firing in Peninsular Malaysia: Implications for cost and GHG emissions in the electricity sector. Energies, 7(2): 804-823.

Gueye, M., Richardson, Y., Kafack, F.T. and Blin, J. 2014. High efficiency activated carbons from African biomass residues for the removal of chromium (VI) from wastewater. J. Environ. Chem. Eng., 2(1): 273-281.

Guo, F., Jiang, X., Li, X., Jia, X., Liang, S. and Qian, L. 2020. Synthesis of $\mathrm{MgO} / \mathrm{Fe} 3 \mathrm{O} 4$ nanoparticles embedded activated carbon from biomass for high-efficient adsorption of malachite green. Mater. Chem. Phy., 240: 122240.

Gupta, H. 2015. Removal of phenanthrene from water using activated carbon developed from orange rind. Int. J, Sci.. Res. Environ. Sci., 3(7): 248-255.

Gupta, H. and Gupta, B. 2015. Adsorption of polycyclic aromatic hydrocarbons on banana peel activated carbon. Desal. Water Treat., 57(20): 9498-9509.

Hamad, B.K., Noor, A.M., Afida, A.R. and Mohd Asri, M.N. 2010. High removal of 4-chloroguaiacol by the high surface area of oil palm shell-activated carbon activated with $\mathrm{NaOH}$ from aqueous solution. Desalination, 257(1-3): 1-7.

Hamza, R.A., Iorhemen, O.T. and Tay, J.H. 2016. Occurrence, impacts, and removal of emerging substances of concern from wastewater. Environ. Technol. Innov., 5: 161-175.

Hassan, M.F., Sabri, M.A., Fazal, H., Hafeez, A., Shezad, N. and Hussain, M. 2020. Recent trends in activated carbon fiber production from various precursors and applications-A comparative review. J. Anal. Appl. Pyrolysis., 145: 104715.

Heidari, A., Younesi, H., Rashidi, A. and Ghoreyshi, A. 2014. Adsorptive removal of $\mathrm{CO}_{2}$ on highly microporous activated carbons prepared from Eucalyptus camaldulensis wood: Effect of chemical activation. J. Taiwan Inst. of Chem. Eng., 45(2): 579-588.

Herawan, S.G., Hadi, M.S., Ayob, M.R. and Putra, A. 2013. Characterization of activated carbons from the oil-palm shell by $\mathrm{CO}_{2}$ activation with no holding carbonization temperature. The Sci. World J., 2013: 1-6.

Hoseinzadeh Hesas, R., Wan Daud, W.M.A., Sahu, J. N. and Arami-Niya, A. 2013. The effects of a microwave heating method on the production of activated carbon from agricultural waste: A review. J. Anal. Appl. Pyrol., 100: 1-11.

Hui, T.S. and Zaini, M.A.A. 2015. Potassium hydroxide activation of activated carbon: A commentary. Carbon Lett., 16(4): 275-280.

Idowu, O., Semple, K.T., Ramadass, K., O'Connor, W., Hansbro, P. and Thavamani, P. 2019. Beyond the obvious: Environmental health implications of polar polycyclic aromatic hydrocarbons. Environ. Int., 123: 543-557.

Ioannidou, O.A., Zabaniotou, A.A., Stavropoulos, G.G., Islam, M.A. and Albanis, T.A. 2010. Preparation of activated carbons from agricultural residues for pesticide adsorption. Chemosphere, 80(11): 1328-1336.

Islam, M.A., Ahmed, M.J., Khanday, W.A., Asif, M. and Hameed, B.H. 
2017. Mesoporous activated coconut shell-derived hydrochar prepared via hydrothermal carbonization- $\mathrm{NaOH}$ activation for methylene blue adsorption. J. Environ. Manag., 203: 237-244.

Jiang, C., Yakaboylu, G.A., Yumak, T., Zondlo, J.W., Sabolsky, E.M. and Wang, J. 2020. Activated carbons prepared by indirect and direct CO2 activation of lignocellulosic biomass for supercapacitor electrodes. Renew. Energy., 155: 38-52.

Kadir, S.A.S.A., Matali, S., Mohamad, N.F. and Abdul Rani, N.H. 2014. Preparation of activated carbon from oil palm empty fruit bunch (EFB) by steam activation using response surface methodology. Int. J. Mater. Sci. Appl., 3(5): 159.

Kalkan, E., Nadaroğlu, H., Celebi, N. and Tozsin, G. 2013. Removal of textile dye reactive black 5 from aqueous solution by adsorption on laccase-modified silica fume. Desal. Water Treat., 52(31-33): 6122-6134.

Kausar, A., Iqbal, M., Javed, A., Aftab, K., Nazli, Z.-i.-H., Bhatti, H.N and Nouren, S. 2018. Dyes adsorption using clay and modified clay: A review. J. Mol. Liq., 256: 395-407.

Kaveeshwar, A.R., Ponnusamy, S.K., Revellame, E.D., Gang, D.D., Zappi, M.E. and Subramaniam, R. 2018. Pecan shell-based activated carbon for removal of iron (II) from fracking wastewater: Adsorption kinetics, isotherm, and thermodynamic studies. Process Saf. Environ. Prot., 114: 107-122.

Khorasani, A.C. and Shojaosadati, S.A. 2019. Magnetic pectin-chlorella vulgaris biosorbent for the adsorption of dyes. J. Environ. Chem. Eng., 7(3): 103062.

Kou, Y., Zhao, Q., Cheng, Y., Wu, Y., Dou, W. and Ren, X. 2020. Removal of heavy metals in sludge via joint EDTA-acid treatment: Effects on seed germination. Sci. Tot. Environ., 707: 135866.

Kumar, J.A., Amarnath, D.J., Sathish, S., Jabasingh, S.A., Saravanan, A., Hemavathy, R.V., Anand, K.V. and Yaashikaa, P.R. 2019. Enhanced PAHs removal using pyrolysis-assisted potassium hydroxide induced palm shell activated carbon: batch and column investigation. J. Mol. Liq., 279: 77-87.

Lakshmi, S.D., Avti, P.K. and Hegde, G. 2018. Activated carbon nanoparticles from biowaste as new generation antimicrobial agents: A review. Nano-Struct. Nano-Objects., 16: 306-321.

Li, W., Zhang, L., Peng, J., Li, N. and Zhu, X. 2008. Preparation of high surface area activated carbons from tobacco stems with $\mathrm{K}_{2} \mathrm{CO}_{3}$ activation using microwave radiation. Ind. Crops and Prod., 27(3): 341-347.

Liang, C.Z., Sun, S.P., Li, F.Y., Ong, Y.K. and Chung, T.S. 2014. Treatment of highly concentrated wastewater containing multiple synthetic dyes by a combined process of coagulation/flocculation and nanofiltration. J. Memb. Sci., 469: 306-315.

Macedo, J. de S., da Costa Júnior, N. B., Almeida, L. E., Vieira, E. F. da S., Cestari, A. R., Gimenez, I. de F., Carreño, N. L. V. and Barreto, L. S. 2006. Kinetic and calorimetric study of the adsorption of dyes on mesoporous activated carbon prepared from coconut coir dust. J. Colloid Interface Sci., 298(2): 515-522.

Mahamad, M.N., Zaini, M.A.A. and Zakaria, Z.A. 2015. Preparation and characterization of activated carbon from pineapple waste biomass for dye removal. Int. Biodeter. Biodegrad., 102: 274-280.

Maneerung, T., Liew, J., Dai, Y., Kawi, S., Chong, C. and Wang, C.H. 2016. Activated carbon derived from the carbon residue from biomass gasification and its application for dye adsorption: Kinetics, isotherms, and thermodynamic studies. Bioresour. Technol., 200: 350-359.

Marican, A. and Durán-Lara, E.F. 2017. A review on pesticide removal through different processes. Environ. Sci. Pollut. Res., 25(3): 2051-2064.

Marsin, F.M., Wan Ibrahim, W.A., Nodeh, H.R., Sutirman, Z.A., Ting, N.N. and Sanagi, M.M. 2018. Recent advances in the preparation of oil palm waste-based adsorbents for removal of environmental pollutants: A review. Malaysian J. Anal. Sci., 22(2): 175-184.

Masjedi, A., Askarizadeh, E. and Baniyaghoob, S. 2020. Magnetic nanoparticles are surface-modified with tridentate ligands for the removal of heavy metal ions from water. Mater. Chemi. Phy., 249: 122917.
Mateo, W., Lei, H., Villota, E., Qian, M., Zhao, Y., Huo, E., Zhang, Q., Lin, X., Wang, C. and Huang, Z. 2020. Synthesis and characterization of sulfonated activated carbon as a catalyst for bio-jet fuel production from biomass and waste plastics. Bioresour. Technol., 297: 122411.

Mazlan, M.A.F., Uemura, Y., Yusup, S., Elhassan, F., Uddin, A., Hiwada, A. and Demiya, M. 2016. Activated carbon from rubberwood sawdust by carbon dioxide activation. Process Eng., 148: 530-537.

Meryemoglu, B., Irmak, S. and Hasanoglu, A. 2016. Production of activated carbon materials from kenaf biomass to be used as catalyst support in the aqueous-phase reforming process. Fuel Process. Technol., 151: 59-63.

Mojiri, A., Zhou, J. L., Ohashi, A., Ozaki, N. and Kindaichi, T. 2019. A comprehensive review of polycyclic aromatic hydrocarbons in water sources, their effects, and treatments. Sci. Tot. Environ., 696: 133971.

Mojiri, A., Zhou, J. L., Robinson, B., Ohashi, A., Ozaki, N., Kindaichi, T., Farraji, H. and Vakili, M. 2020. Pesticides in aquatic environments and their removal by adsorption methods. Chemosphere, 253: 126646.

Muniandy, L., Adam, F., Mohamed, A.R. and Ng, E.P. 2014. The synthesis and characterization of high purity mixed microporous/mesoporous activated carbon from rice husk using chemical activation with $\mathrm{NaOH}$ and KOH. Micropor. Mesopor. Mate., 197: 316-323.

Nabais, J.M.V., Laginhas, C., Carrott, M.M.L.R., Carrott, P.J.M., Amorós, J.E.C. and Gisbert, A.V.N. 2013. Surface and porous characterization of activated carbons made from a novel biomass precursor, the esparto grass. Appl. Surf. Sci., 265: 919-924.

Naik, P.K., Paul, S. and Banerjee, T. 2017. Liquid equilibria measurements for the extraction of polyaromatic nitrogen hydrocarbons with a lowcost deep eutectic solvent: Experimental and theoretical insights. J. Mol. Liq., 243: 542-552.

Narayana, S.J. and Kariyajjanavar, P. 2019. Studies on degradation of pulp and paper mill industrial dye fast red by indirect electrochemical method. Nat. Env. Pollut. Technol., 18(2): 657-662.

Ndiaye, P.I., Moulin, P., Dominguez, L., Millet, J.C. and Charbit, F. 2005. Removal of fluoride from electronic industrial effluent by RO membrane separation. Desalination., 173(1): 25-32.

Nidheesh, P.V., Zhou, M. and Oturan, M.A. 2018. An overview on the removal of synthetic dyes from water by electrochemical advanced oxidation processes. Chemosphere, 197: 210-227.

Nie, J., Sun, Y., Zhou, Y., Kumar, M., Usman, M., Li, J., Shao, J., Wang, L. and Tsang, D.C. W. 2020. Bioremediation of water containing pesticides by microalgae: Mechanisms, methods, and prospects for future research. Sci. Tot. Environ., 707: 136080.

Njoku, V.O., Islam, M.A., Asif, M. and Hameed, B.H. 2014. Preparation of mesoporous activated carbon from coconut frond for the adsorption of carbofuran insecticide. J. Anal. Appl. Pyrolysis, 110: 172-180.

Pagketanang, T., Artnaseaw, A., Wongwicha, P. and Thabuot, M. 2015. Microporous activated carbon from $\mathrm{KOH}$-activation of rubber seed-shells for application in Capacitor Electrode. Energy Procedia, 79: 651-656.

Pereira, R.G., Veloso, C.M., da Silva, N.M., de Sousa, L.F., Bonomo, R.C.F., de Souza, A.O., da Guarda Souza., M.O. and da Costa, I.F.R. 2014. Preparation of activated carbons from cocoa shells and siriguela seeds using $\mathrm{H}_{3} \mathrm{PO}_{4}$ and $\mathrm{ZnCl}_{2}$ as activating agents for BSA and $\alpha$-lactalbumin adsorption. Fuel Process. Technol., 126: 476-486.

Pérez-Gregorio, M.R., García-Falcón, M.S., Martínez-Carballo, E. and Simal-Gándara, J. 2010. Removal of polycyclic aromatic hydrocarbons from organic solvents by ashes wastes. J. Hazard. Mater., 178(1-3): 273-281.

Prashanthakumar, T.K.M., Ashok Kumar, S.K. and Sahoo, S.K. 2018. A quick removal of toxic phenolic compounds using porous carbon prepared from renewable biomass coconut spathe and exploration of a new source for porous carbon materials. J. Env. Chem. Eng., 6(1), 1434-1442.

Purnomo, C.W., Kesuma, E.P., Perdana, I. and Aziz, M. 2018. Lithium recovery from spent Li-ion batteries using coconut shell activated carbon. Waste Manag., 79: 454-461. 
Rahman, M., Adil, M., Yusof, A., Kamaruzzaman, Y. and Ansary, R. 2014. Removal of heavy metal ions with acid-activated carbons derived from oil palm and coconut shells. Materials, 7(5): 3634-3650.

Rai, P., Gautam, R.K., Banerjee, S., Rawat, V. and Chattopadhyaya, M.C. 2015. Synthesis and characterization of a novel $\mathrm{SnFe}_{2} \mathrm{O}_{4} @$ activated carbon magnetic nanocomposite and its effectiveness in the removal of crystal violet from an aqueous solution. J. Environ. Chem. Eng., 3(4): 2281-2291.

Ratna, K. and Padhi, B.S. 2012. Pollution due to synthetic dye toxicity and carcinogenicity studies and remediation. Int. J. Environ. Sci., 3(3): 940-947.

Rizzi, V., Prasetyanto, E.A., Chen, P., Gubitosa, J., Fini, P., Agostiano, A., De Cola, L. and Cosma, P. 2019. Amino grafted MCM-41 as a highly efficient and reversible eco-friendly adsorbent material for the Direct Blue removal from wastewater. J. Mol. Liq., 273: 435-446.

Saba, N., Jawaid, M., Hakeem, K.R., Paridah, M.T., Khalina, A. and Alothman, O.Y. 2015. Potential of bioenergy production from industrial kenaf (Hibiscus cannabinus L.) based on Malaysian perspective. Renew. Sustain. Energy Rev., 42: 446-459.

Salman, J.M., Njoku, V.O. and Hameed, B.H. 2011. Batch and fixed-bed adsorption of 2,4-dichlorophenoxyacetic acid onto oil palm frond activated carbon. Chem. Eng. J., 174(1): 33-40.

Sapahin, H.A., Makahleh, A. and Saad, B. 2014. Determination of organophosphorus pesticide residues in vegetables using solid-phase micro-extraction coupled with gas chromatography-flame photometric detector. Arabian J. Chem., 2015: 1-11.

Sekar, A.S.S. 2008. Removal of color from tannery dye wastewater using ozone. Nat. Env. Pollut. Technol., 7(3): 505-508.

Sellaoui, L., Lima, É. C., Dotto, G. L., Dias, S. L. P. and Ben Lamine, A. 2017. Physicochemical modeling of reactive violet 5 dye adsorption on the homemade cocoa shell and commercial activated carbons using the statistical physics theory. Results in Physics., 7: 233-237.

Sharma, S., Mathur, S. and Sharma, R. 2011. Efficacy of electrocoagulation in the treatment of textile wastewater containing basic red dye using iron electrodes. Nat. Environ. Pollut. Technol., 10(2): 225-228.

Shukla, K., Verma, A., Verma, L., Rawat, S. and Singh, J. 2020. A novel approach to utilize used disposable paper cups for the development of adsorbent and its application for the malachite green and rhodamine-B dyes removal from aqueous solutions. Nat. Environ Pollut. Technol., 19(1): 57-70.

Sulaiman, F., Abdullah, N., Gerhauser, H. and Shariff, A. 2011. An outlook of Malaysian energy, oil palm industry and its utilization of wastes as useful resources. Biomass Bioenerg., 35(9): 3775-3786.

Sun, Y., Lan, J., Du, Y., Li, Z., Liao, X., Du, D., Ye, H., Zhang, T. C. and Chen, S. 2020. Efficient removal of heavy metals by synergistic actions of microorganisms and waste molasses. Bioresour. Technol., 302: 122797.

Tan, I.A.W., Ahmad, A.L. and Hameed, B.H. 2008. Adsorption of basic dye using activated carbon prepared from oil palm shell: batch and fixed bed studies. Desalination, 225(1-3): 13-28.

Teimouri, Z., Salem, A. and Salem, S. 2019. Clean and new strategy for catalytic conversion of agriculture waste shells to activated carbon via microwave-assisted impregnation: Applied and eco-friendly aspect for decoloration of industrial corn syrup and process identifications. J. Environ. Chem. Eng., 7(3): 103161.

Tobiszewski, M. and Namieśnik, J. 2012. PAH diagnostic ratios for the identification of pollution emission sources. Environ. Pollut., 162: 110-119.

Tounsadi, H., Khalidi, A., Abdennouri, M. and Barka, N. 2016. Activated carbon from Diplotaxis Harra biomass: Optimization of preparation conditions and heavy metal removal. J. Taiwan Inst. Chem. Eng., 59: 348-358.

Treviño-Cordero, H., Juárez-Aguilar, L.G., Mendoza-Castillo, D.I., Hernández-Montoya, V., Bonilla-Petriciolet, A. and Montes-Morán, M.A. 2013. Synthesis and adsorption properties of activated carbons from biomass of Prunus domestica and Jacaranda mimosifolia for the removal of heavy metals and dyes from water. Ind. Crops Prod., 42: 315-323.

Tripathi, M., Dixit, A. and Bobade, S.M. 2020. Fabrication of supercapacitor using banyan leaves-based activated carbon electrode and formic acid-based polymer electrolyte. Mater. Today: Proceed., 28: 320-324.

Tsibart, A.S. and Gennadiev, A.N. 2013. Polycyclic aromatic hydrocarbons in soils: Sources, behavior, and indication significance (a review). Eurasian Soil Sci., 46(7): 728-741.

Ufodike, C.O., Eze, V.O., Ahmed, M.F., Oluwalowo, A., Park, J.G., Liang, Z. and Wang, H. 2020. Investigation of molecular and supramolecular assemblies of cellulose and lignin of lignocellulosic materials by spectroscopy and thermal analysis. Int. J. Biol. Macromol., 146: 916-921.

Wahi, R., Ngaini, Z. and Uson Jusok, V. 2009. Review of removal of mercury, lead, and copper from aqueous solution by activated carbon of palm oil empty fruit bunch. World Appl. Sci. J., 5: 84-91.

Włóka, D., Placek, A., Smol, M., Rorat, A., Hutchison, D. and Kacprzak, M. 2019. The efficiency and economic aspects of phytoremediation technology using Phalaris arundinacea L. and Brassica napus L. combined with compost and nano $\mathrm{SiO}_{2}$ fertilization for the removal of PAH's from the soil. J. Environ. Manag., 234: 31-319.

Xue, C., Hao, W., Cheng, W., Ma, J. and Li, R. 2019. Effects of the pore size distribution of activated carbon (AC) on $\mathrm{CuCl}$ dispersion and $\mathrm{CO}$ adsorption for $\mathrm{CuCl} / \mathrm{AC}$ adsorbent. Chem. Eng. J., 375: 122049.

Yacob, A. R., Wahab, N., Suhaimi, N. H. and Mustajab, M. K. A. A. 2013. Microwave-induced carbon from waste palm kernel shell activated by phosphoric acid. Int. J. Eng. Technol., 5(2): 214-217.

Yakout, S.M. and Sharaf El-Deen, G. 2012. Characterization of activated carbon prepared by phosphoric acid activation of olive stones. Arab. J. Chem., 9: S1155-S1162.

Yakout, S. M., Daifullah, A. A. M. and El-Reefy, S. A. 2013. Adsorption of naphthalene, phenanthrene, and pyrene from aqueous solution using low-cost activated carbon derived from agricultural wastes. Adsorp. Sci. Technol., 31(4): 293-302.

Yang, Z., Asoh, T. A. and Uyama, H. 2019. Removal of cationic or anionic dyes from water using ion-exchange cellulose monoliths as adsorbents. Bull. Chem. Soc. Japan., 92(9): 1453-1461.

Yang, W., Chen, H., Han, X., Ding, S., Shan, Y. and Liu, Y. 2020. Preparation of magnetic $\mathrm{Co}-\mathrm{Fe}$ modified porous carbon from agricultural wastes by microwave and steam activation for mercury removal. J. Hazard. Mater., 381: 120981.

Zhang, Y., Song, X., Zhang, P., Gao, H., Ou, C. and Kong, X. 2020. Production of activated carbons from four wastes via one-step activation and their applications in $\mathrm{Pb} 2+$ adsorption: Insight of ash content. Chemosphere, 245: 125587.

Zhou, J., Luo, A. and Zhao, Y. 2018. Preparation and characterization of activated carbon from waste tea by physical activation using steam. J. Air Waste Manag. Assoc., 68(12): 1269-1277. 